\title{
First recorded occurrence of Cheirocratus robustus Sars, 1894 in the British Isles
}

\author{
Alan A. Myers ${ }^{1 *}$, David McGrath ${ }^{2}$ and Will Musk ${ }^{3}$
}

\begin{abstract} Mediterranean is provided. overlooked.

Keywords: Amphipoda, Cheirocratus robustus, British Isles, New record

\section{Background}

Collections of Cheirocratus from the Humber region of the North Sea and from several localities on the West Coast of Ireland, proved to include specimens of $C$. robustus Sars, a species previously recorded only from Norway and Sweden and probably overlooked elsewhere.
\end{abstract}

Background: Collections of the amphipod genus Cheirocratus from the North Sea and Ireland proved to include C. robustus Sars a species previously known only from Norway and Sweden.

Results: Material of C.robustus is described and figured from the Humber and Ireland together with the closely related species C. sundevalli (Rathke). A key to males of the Cheirocratus species of the North East Atlantic and

Conclusions: C. robustus is shown to be widespread in the eastern North Atlantic where it was previously

\section{Methods}

Specimens were preserved in $70 \%$ ethanol. Dissection was made under a Wild stereomicroscope and body parts were mounted on microscope slides in glycerine for drawing with a drawing tube on a Nikon compound microscope. In the diagnoses, character states that distinguish $C$. robustus from $C$. sundevallii are listed in bold.

Material is deposited in the National Museum of Ireland, Natural History. (NMINH) and Goteborgs Naturhistorika Museum (GNM) Sweden.

\section{Results}

\section{Systematics}

Order Amphipoda Latreille, (Latreille 1816)

Suborder Senticaudata Lowry \& Myers, (Lowry \& Myers 2013)

\footnotetext{
* Correspondence: bavayia@gmail.com

${ }^{1}$ School of Biological, Earth and Environmental Sciences, University College

Cork, Cork Enterprise Centre, Distillery Fields, North Mall, Cork, Ireland

Full list of author information is available at the end of the article
}

Infraorder Hadziida S. Karaman, (Karaman 1932)

Superfamily Calliopioidea Sars, (Sars 1893)

Family Cheirocratidae d'Udekem d'Acoz, (D'Udekem d'Acoz 2010)

Cheirocratus robustus Sars.

(Figs. 1, 2 and 3)

Cheirocratus robustus Sars, (Sars 1894): 526, pl. 185, fig. 2.-Oldevig, (Oldevig 1932): 186, pl.2, fig. 2.

\section{Material examined}

Three males, six females (NMINH 2016.16.1), RSMP H 0205 Baseline $\left(53.431843^{\circ} \mathrm{N}, 0.38073^{\circ} \mathrm{E}\right)$, Humber region of North Sea, 10 m depth, gravel, 23.09.2014, IECS (collected by MESL) one male, one female (NMINH 2016.16.2) RSMP H 0293 Baseline $\left(53.414395^{\circ} \mathrm{N}, 0.52727^{\circ} \mathrm{E}\right)$, Humber region of North Sea, 12 m depth, gravel, 23.09.2014, IECS (collected by MESL); one female (NMINH 2016.16.3), RSMP H 0211 Baseline $\left(53.437086^{\circ} \mathrm{N}, 0.398443^{\circ} \mathrm{E}\right)$, Humber region of North Sea, $11 \mathrm{~m}$ depth, gravel, 23.09.2014, IECS (collected by MESL); one male (NMINH 2016.16.4), Marine Harvest salmon farm, Inishdoonver, Clew Bay, Co Galway, Ireland, $21.5 \mathrm{~m}$ depth, current $17 \mathrm{~cm} / . \mathrm{sec}, 50 \mathrm{~m}$ from edge of salmon cage, 07.08.2013; one male (NMINH 2016.16.5), JN1067, Rutland Island, 01.09.2010, RUG38; three males, eight females, two immature (NMINH 2016.16.6), JN1006, Kilkieran, 14.10.2010, KKG 17; two males, three females (NMINH 2016.16.7), JN1066, Valentia 16.9.2010, VAG 14; three males, (NMINH 2016.16.8) Hum Agg, 2014, sample 

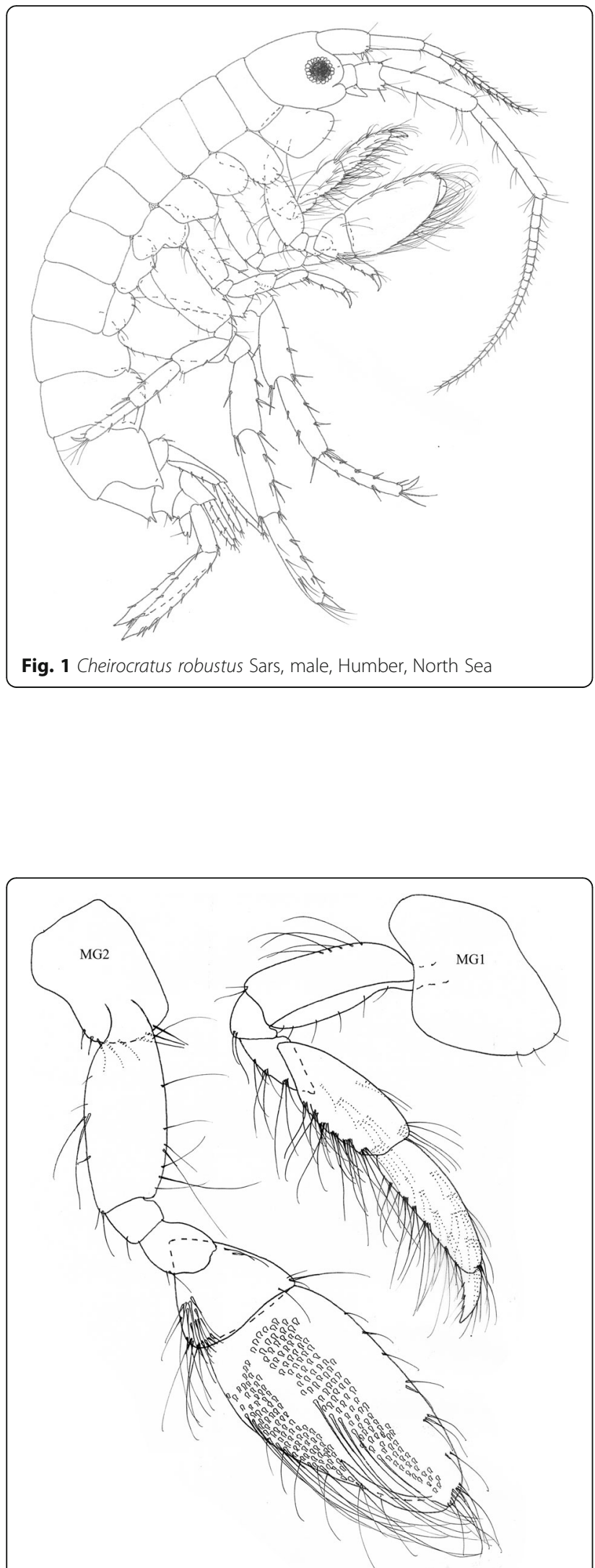

Fig. 2 Cheirocratus robustus Sars, male, Humber, North Sea

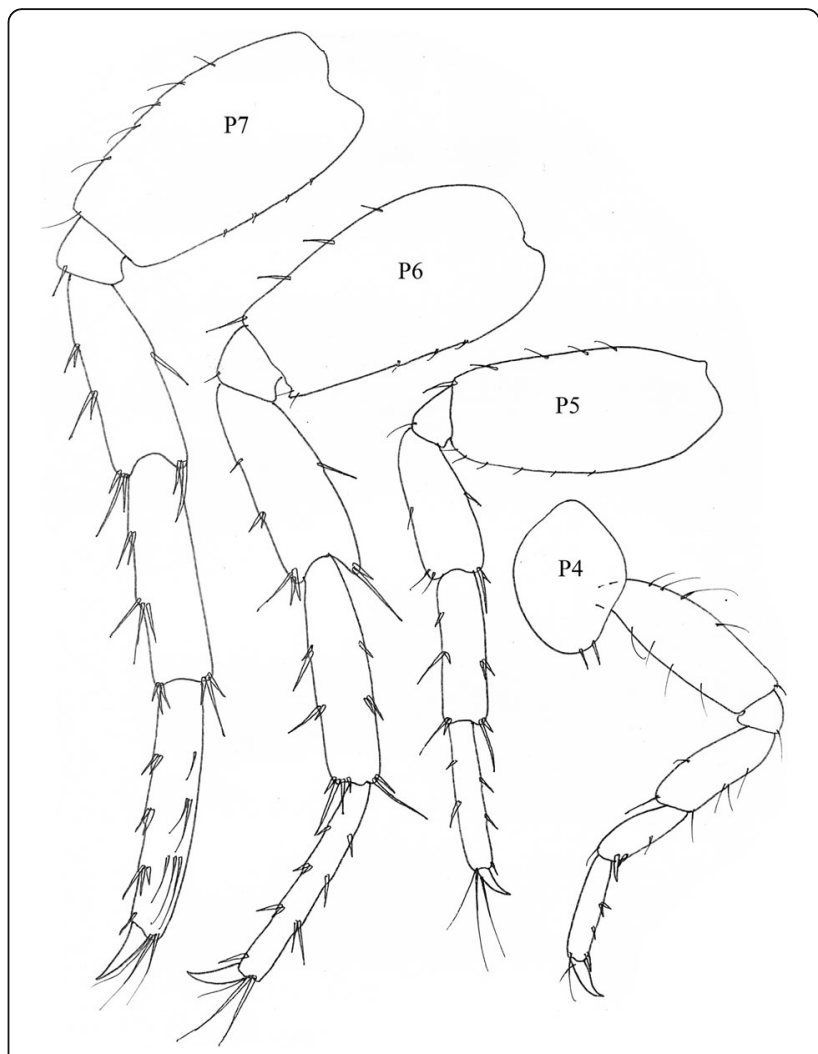

Fig. 3 Cheirocratus robustus Sars, male, Humber, North Sea

523; 11 males, seven females, (GNM 9907), Gullmarfjord, Gullmar strömmar, Sweden, 58 $15^{\prime} 10^{\prime \prime} \mathrm{N} 11^{\circ} 30^{\prime} 00^{\prime \prime} \mathrm{E}, 15 \mathrm{~m}$, stone, gravel and sand, living and dead algae, 31.07.1921, Hugo Oldevig; two males, three females, (GNM 9908) Gullmarfjord, Gullmar strömmar, Sweden, $58^{\circ} 15^{\prime} 10^{\prime \prime} \mathrm{N} 11^{\circ} 30^{\prime}$ 00"E, 6-10 m, dead algae, gravel. 31.07.1921, Hugo Oldevig.

\section{Diagnosis}

Head with cheek notch; antenna 2 much longer than antenna 1; male gnathopod 2 much larger than gnathopod 1 ; male gnathopod 1 robust, basis subovoid, without anterodistal spine, carpus and propodus subequal in length, dactylus stout; male gnathopod 2 propodus inner face heavily clothed in long setae, inner face without medial ridge, spine or robust setae, but with small bifid protrubence distally; pereopods 5-7 robust, pleon segment 1 with three strong dorsal spines; uropod 3 biramous, rami long, subequal in length, distally acute.

\section{Discussion}

This is the first record of C. robustus Sars from the British Isles. It was previously known only from Norway, Sars, (Sars 1894) (59 $91^{\prime} 23^{\prime \prime} \mathrm{N}, 10^{\circ} 744^{\prime} 92^{\prime \prime} \mathrm{E}$ to $63^{\circ} 43^{\prime} 05^{\prime \prime} \mathrm{N}, 10^{\circ} 39^{\prime} 51^{\prime \prime} \mathrm{E}$ ) and Sweden (see material examined). It can be distinguished in general from its close congener $C$. sundevallii by its much more 
robust appendages. The male gnathopod 1 lacks an anterodistal spine on the basis, has the carpus and propodus subequal in length, and has a stout dactylus (C. sundevallii male gnathopod 1 has anterodistal spine, carpus much longer than propodus and a slender dactylus). In $C$. robustus, the gnathopod 2 has dense setae over much of the inner face of the propodus that lacks ridges, spine or robust setae medially on the inner face. It does have a small protrubence on the distal end of the inner face but this cannot be viewed without removal of some of the dense setation (C. sundevallii has dense setae restricted to the outer margin of the inner face of the propodus and has a ridge on the inner face bearing medially a spine and two robust setae and distally a blunt irregular spine bearing a robust seta). The absence of $C$. robustus from the diagnostic key to Irish and British marine Amphipoda in Lincoln (Lincoln 1979) and the superficial similarity of $C$. robustus to C. sundevallii probably explains why $C$. robustus was overlooked in the past and confused with $C$. sundevalili. All previous records of $C$. sundevallii in British and Irish waters must be regarded with caution.

Cheirocratus sundevallii (Rathke)

(Fig. 4)

Gammarus sundevallii Rathke, (Rathke 1843): 65.
Cheirocratus sundevallii: Stebbing, (Stebbing 1888): 204.- Stebbing, (Stebbing 1906): 418.- Chevreux \& Fage, (Chevreux \& Fage 1925): 223.- Lincoln, (Lincoln 1979): 308, fig. 144.- Karaman, (Karaman 1982): 267, fig. 182. Cheirocratus sundewallii: Sars, (Sars 1894): 524, pl. 184, 185.

Liljeborgia shetlandica Bate \& Westwood, (Bate \& Westwood 1863): 206.

Protomedeia whitei Bate, (Bate 1862): 169.

\section{Material examined}

Three males, five females (NMINH 2016.16.9), JN1066, Valentia, 16.9.2010, VAG 13; one male (NMINH 2016.16.10), JN1066, Valentia, 16.9.2010, VAG 16; two males, one female (NMINH 2016.16.11), JN1066, Valentia,16.9.2010, VAG 14; one male, one female (NMINH 2016.16.12), Carnsore point, C72 52.267 N 6.213 W in 29 m, 1977, Gravel, D. McGrath.

\section{Diagnosis}

Head with cheek notch; antenna 2 much longer than antenna 1; male gnathopod 2 much larger than gnathopod 1 ; male gnathopod 1 very slender, basis subovoid, with strong anterodistal spine, carpus much longer than propodus, dactylus slender; male gnathopod 2 basis with small anterodistal spine, propodus heavily clothed in long setae on the posterior margin of the

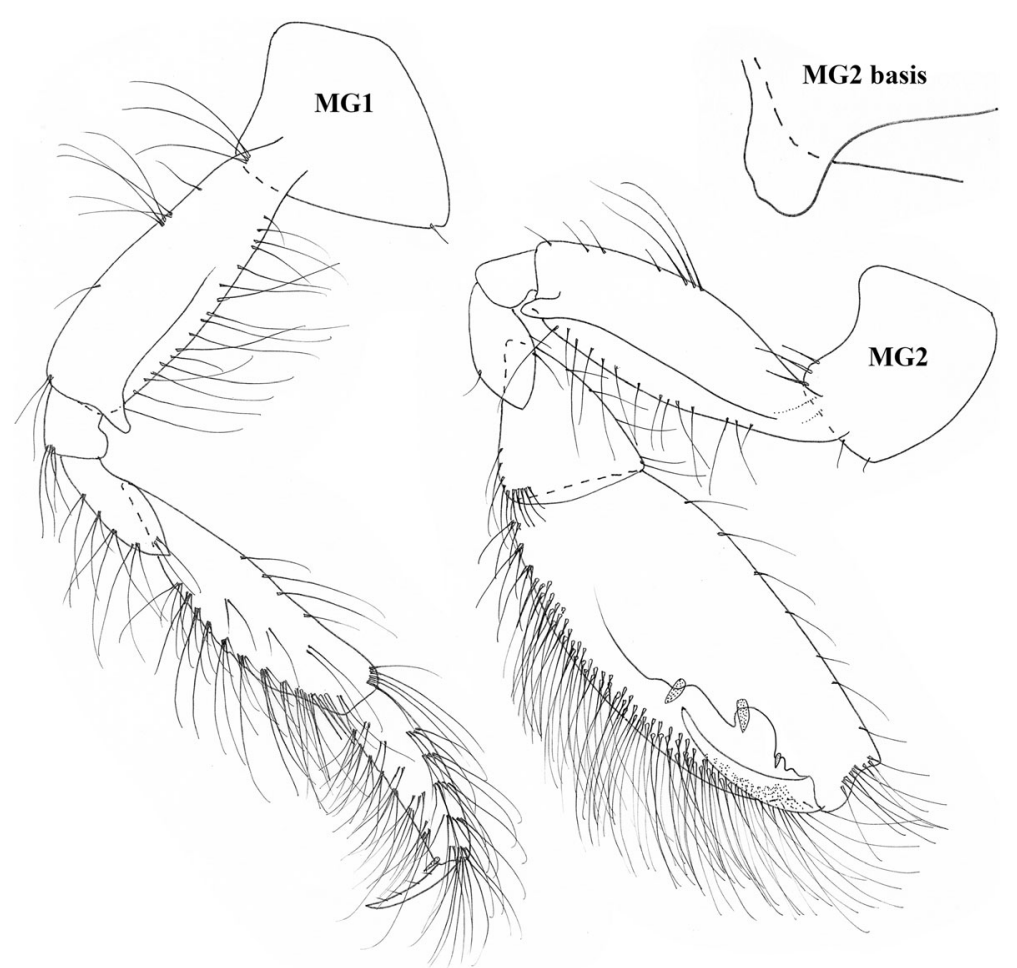

Fig. 4 Cheirocratus sundevallii (Rathke), male, Valentia, Ireland 
inner face, lacking long setae on the centre of the inner face, but with scalloped ridge bearing a spine and two (Lincoln (1979) figures three) robust setae medially and a small, blunt, irregular spine distally that bears a robust seta; pereopods 5-7 relatively feeble, pleon segment 1 with three strong dorsal spines; uropod 3 biramous, rami long, subequal in length, distally acute.

\section{Discussion}

C. sundevalli is widespread in the North East Atlantic and Mediterranean. For differences between $C$. sundevalli and $C$. robustus, see the remarks for that species.

Key to the male Cheirocratus of the N.E. Atlantic and Mediterranean

1. Urosome segment 1 with median dorsal spine. C. monodontus Urosome segment 1 with three dorsal spines.

2. Gnathopod 2 propodus palm with multiple spines. C. assimilis Gnathopod 2 propodus palm without spines.

3. Gnathopod 2 propodous broadest proximally, dactylus not folding across face of propodus......C. intermedius Gnathopod 2 propodous sub-ovoid, dactylus folding across face of propodus

4. Gnathopod 1 basis without anterodistal spine, propodus equal to carpus; gnathopod 2 basis without anterodistal spine, propodus inner face clothed in dense and very long setae and lacking medial spine or robust setae. C. robustus

Gnathopod 1 basis with anterodistal spine, propodus half the length of carpus; gnathopod 2 basis with anterodistal spine, propodus with dense very long setae on posterior margin of inner face only and with a medial ridge bearing a spine and $2-3$ robust setae. C. sundevallii

\section{Conclusions}

Cheirocratus robustus Sars previously known only from Norway and Sweden is now shown to be widespread in the British Isles, occurring in the North Sea and along the west coast of Ireland.

\section{Abbreviations}

G1-2: Gnathopod 1-2; M: Male; P3-7: Pereopods 3-7

\section{Acknowledgements}

The authors would like to thank Mark Russell from British Marine Aggregate Producers Association (BMAPA), Tarmac Marine Ltd and Hanson Aggregates Marine Ltd for permission to use their PSA and survey data, Keith Cooper from the Centre for Environment, Fisheries and Aquaculture Science (Cefas), for providing PSA and survey data, and Marine Ecological Surveys Limited (MESL) for collecting the North Sea specimens. We wish to thank Dr Kennet Lundin for the loan of C. robustus from the Goteborg Naturhistorika Museum and for locality data and Dr. Eddie McCormack of Aquafact International Services Ltd. for making available Irish C. robustus material.
Funding

No funding was available.

Availability of data and materials

Material is stored in the National Museum of Ireland Natural History, Dublin and Goteborgs Naturhistorika Museum (GNM) Sweden.

\section{Authors' contributions}

Taxonomic expertise, descriptions and illustrations of taxa AM, Taxonomic expertise DMcG, collection and ecological input WM. All authors read and approved the final manuscript.

\section{Competing interests}

The authors declare that they have no competing interests.

\section{Consent for publication}

Consent to publication has been granted by the British Marine Aggregate Producers Association, Tarmac Marine Ltd and Hanson Aggregates Marine Ltd.

Ethics approval and consent to participate

There are no ethical considerations.

\section{Author details}

${ }^{1}$ School of Biological, Earth and Environmental Sciences, University College Cork, Cork Enterprise Centre, Distillery Fields, North Mall, Cork, Ireland.

${ }^{2}$ Department of Natural Sciences, Galway and Mayo Institute of Technology, Dublin Road, Galway, Ireland. ${ }^{3}$ Institute of Estuarine \& Coastal Studies (IECS), University of Hull, Cottingham Road, Hull HU6 7RX, UK.

Received: 1 November 2016 Accepted: 4 January 2017

Published online: 13 January 2017

\section{References}

Bate CS. Catalogue of the Specimens of Amphipodous Crustacea in the Collection of the British Museum. London: Trustees, British Museum; 1862. p. 1-399.

Bate CS, Westwood JO. A History of the British Sessile-eyed Crustacea. London: John van Voorst: 1863. p. 1-507.

Chevreux E, Fage L. Amphipodes. Faune de France. 1925;9:1-488.

D'Udekem d'Acoz C. Contribution to the knowledge of European Liljeborgiidae (Crustacea, Amphipoda), with considerations on the family and its affinities. Bull Inst Roy Sci Nat Belg. 2010;80:127-259.

Karaman S. Beitrage zur Kenntnis der Süsswasser-Amphipoden. Prirod Razp. 1932;2:179-232

Karaman GS. Family Gammaridae. In: Ruffo S, editor. The Amphipoda of the Mediterranean, Part III, vol. 13. Monaco: Mém Inst Océanogr; 1982. p. 245-364.

Latreille PA. Amphipoda. In: Nouveau Dictionaire d'histoire naturelle, appliquée aux Arts, à I'Agriculture à l'Économie rurale et domestique à la Médecine etc. Par une societé de Naturalistes et d'Agriculteurs. $2^{\text {nd }}$ edition, volume 1. Paris: Deterville; 1816. p. 467-9.

Lincoln RJ. British Marine Amphipoda: Gammaridea. London, British Museum (Natural History). 1979. p. 1-658.

Lowry JK, Myers AA. A Phylogeny and Classification of the Senticaudata subord. nov. (Crustacea: Amphipoda). Zootaxa. 2013;3610(1):1-80.

Oldevig H. Sveriges Amphipoder. Got Kungl Vetenskaps Vitterh-Samhalles Handl. 1932;ser. B,3(4):1-282

Rathke H. Beitrage zur Fauna Norwegens. Verh Kaiser Leop-Carol Akad Natur, Breslau. 1843;20(1):1-264,264b,264c.

Sars GO. An account of the Crustacea of Norway, with short descriptions and figures of all the species. Part 16 Paramphithoidae, Epimeridae (part); Part 17 Epimeridae (concluded), Syrrhoidae (part); Part 18 Syrrhoidae (concluded), Pardaliscidae (part); Part 19 Pardaliscidae (concluded), Eusiridae; Part 20 Calliopiidae (part); Part 21 Calliopiidae (concluded), Atylidae. Christiania and Copenhagen (Cammermeyers).1893;p.341-472, pls.121-168.

Sars GO. An account of the Crustacea of Norway, with short descriptions and figures of all the species. Part 22 Gammaridae (part); Part 23 Gammaridae (continued); Part 24 Gammaridae (concluded), Photiidae (part); Part 25/26 Photiidae (concluded), Podoceridae (part); Part 27/28 Podoceridae (concluded), Corophiidae, Cheluridae; Part 29/30 Dulichiidae, Caprellidae, Cyamidae. Christiania and Copenhagen (Cammermeyers). 1894;p. 473-671. pis169 240.

Stebbing TRR. Report on the Amphipoda collected by H.M.S. Challenger during the years 1873-1876. Rep Sci Res H.M.S. Challenger 1873-76. Zoology. 1888; 29:1-1737. pls 1-210.

Stebbing TRR. Amphipoda. I. Gammaridea. Das Tierreich. 1906;2:1-806. 